\title{
PENGARUH KEPEMILIKAN DAN KEPEMIMPINAN KELUARGA SERTA EFEKTIFITAS PENGAWASAN DEKOM TERHADAP KUALITAS AUDIT
}

\author{
Vera Diyanty \\ veranabila@gmail.com \\ Eliza Fatima \\ Akhmad Syahroza \\ Universitas Indonesia
}

\begin{abstract}
This study aims to investigate the effect of family ownership, family leadership, and the monitoring role of the Board of Commissioners on the audit quality. This study uses a sample of non-financial companies listed on the Indonesia Stock Exchange (IDX) from 2010 to 2013. Family ownership is measured through the ultimate ownership of the company. To determine whether the company's CEO is the founder of the company, family relationship data is used on all of the company's ultimate owners. The monitoring role of the Board of Commissioners is calculated through the Asean Corporate Governance Scorecard index. Data of auditor is obtained from Center for Supervision of Financial Service (P2PK). The results showed that family ownership either through direct or indirect mechanisms tend to choose Big 4 KAP than non Big 4. While Chief Financial Officer (CFOs) from family and corporate founders tend to choose Big 4 in auditing the company. This is done to maintain the company's reputation. The results also show that the effective monitoring of the Board of Commisionners (BOC) tends to choose Big 4 auditors compared to non Big 4.
\end{abstract}

Key words: audit quality family ownership; family leadership and board of commisioners

\begin{abstract}
ABSTRAK
Penelitian ini bertujuan untuk menginvestigasi pengaruh kepemilikan keluarga dan kepemimpinan keluarga serta fungsi pengawasan dewan komisaris terhadap kualitas Audit. Penelitian ini menggunakan sampel perusahaan non keuangan yang terdaftar di Bursa Efek Indonesia (BEI) dari tahun 2010 sampai dengan tahun 2013. Indentifikasi Kepemilikan keluarga dilakukan dengan melakukan penelusuran sampai kepemilikan ultimate. Kepemilikan keluarga diukur melalui kepemilikan pengendali akhir dari perusahaan. Untuk menentukan apakah pimpinan utama perusahaan tersebut merupakan pendiri perusahaan, digunakan data hubungan keluarga pada seluruh pengendali akhir perusahaan. Untuk data auditor diperoleh data P2PK (Pusat Pembinaan Profesi Keuangan).Sedangkan Pengawasan Dewan Komisaris dihitung melalui indeks ASEAN Corporate Governance Scorecard. Hasil penelitian menunjukkan bahwa kepemilikan keluarga baik melalui mekanisme langsung maupun tidak langsung cenderung memilih Kantor Akuntan Publik (KAP) Big 4 dibandingkan non Big 4. Sedangkan Chief Financial Officer (CFO) yang berasal dari keluarga dan merupakan pendiri perusahaan cenderung untuk memilih Big4 dalam mengaudit perusahaannya. Hal ini dilakukan untuk menjaga reputasi perusahaan. Hasil penelitian juga menunjukkan bahwa pengawasan yang efektif dari Dewan Komisaris cenderung untuk memilih auditor Big 4 dibanding non Big 4 .
\end{abstract}

Kata kunci: kualitas audit, kepemilikan keluarga, kepemimpinan keluarga dan dewan komisaris 


\section{PENDAHULUAN}

Adanya pemisahan kepemilikan dan pengendalian dalam perusahaan mendorong terjadinya suatu konflik keagenan antara agen yang mengelola perusahaan dengan prinsipal sebagai pemilik perusahaan (Jensen dan Meckling, 1976). Konflik ini akan terjadi pada perusahaan yang memiliki struktur kepemilikan yang menyebar. Struktur kepemilikan yang tersebar ini sebagian besar ditemukan di negara-negara yang memiliki perlindungan hukum yang kuat dan menganut common law (La Porta et al., 1999).

Negara-negara yang memiliki perlindungan hukum yang lemah seperti yang terjadi hampir di sebagian besar negara di Asia Timur, memiliki struktur kepemilikan yang terkonsentrasi (Claessens et al., 2000). Konsentrasi kepemilikan ini menggeser konflik keagenan yang terjadi di perusahaan yaitu konflik antara pemegang saham pengendali dan manajemen dengan pemegang saham non pengendali, yang disebabkan dengan adanya ekspropriasi yang dilakukan oleh pemegang saham pengendali terhadap pemegang saham non pengendali.

Kepemilikan dan pengendalian oleh keluarga dapat diperoleh baik melalui mekanisme kepemilikan langsung ataupun mekanisme kepemilikan yang membentuk struktur piramida (La Porta et al., 1999). Kondisi kepemilikan melalui mekanisme piramida menyebabkan suatu keluarga dapat mengendalikan sebuah perusahaan dengan persentase rantai kepemilikan dan memungkinkan perusahaan dapat mengendalikan perusahaan dengan persentase kepemilikan dan investasi yang relatif lebih kecil dan mendorong hak kendali melebihi hak arus kas sehingga memotivasi terjadinya efek negative entrenchment (Claessens et al., 2000; Diyanty, 2012). Sedangkan dengan mekanisme kepemilikan langsung akan mendorong terjadinya efek alignment karena hak arus kas yang dimiliki sebesar hak kendali yang diperoleh.
Kepemilikan keluarga melalui mekanisme kepemilikan piramida mendorong terjadinya konflik keagenan antara pihak keluarga sebagai pemegang saham mayoritas dengan pemegang saham minoritas lainnya (Claessens et al., 1999a; Diyanty, 2012). Struktur kepemilikan di Indonesia sebagian besar terkonsentrasi pada keluarga dimana sekitar lebih dari $50 \%$ perusahaan publik dikendalikan oleh keluarga tertentu (Diyanty, 2012; Ulupui, 2009). Kondisi ini berdampak pada dorongan untuk menempatkan keluarga pada posisi manajemen dan komisaris yang pada akhirnya akan berdampak pada penentuan kebijakan strategis perusahaan yang mempengaruhi kesejahteraan pemegang saham minoritas atau non pengendali.

Fan dan Wong (2005) menunjukkan bahwa perusahaan yang memiliki konflik keagenan antara pemegang saham pengendali dan nonpengendali cenderung menggunakan auditor Big 5, dan perusahaan tersebut memiliki diskonto harga saham yang lebih rendah. Diskonto harga saham yang lebih rendah tersebut menggambarkan bahwa auditor dapat membantu mengurangi masalah ekspropriasi yang mengurangi nilai pasar perusahaan.

Selain menggunakan auditor untuk meyakinkan pemegang saham nonpengendali bahwa kepentingan mereka akan dilindungi seperti pada penelitian Fan dan Wong (2005) di atas, pemegang saham pengendali juga dapat menggunakan auditor untuk menutupi ekspropriasi yang mereka lakukan. Pemegang saham pengendali bisa saja memilih auditor berkualitas rendah agar ekspropriasi yang mereka lakukan tidak terungkap. Penelitian Choi et al. (2008) menunjukkan bahwa pada perusahaan yang kepemilikannya berbentuk struktur piramida, biaya auditnya lebih rendah, dan akan semakin rendah jika selisih antara hak pengendalian dan hak arus kas pemegang saham pengendalinya semakin besar. Hasil penelitian tersebut juga konsisten dengan hasil penelitian Lin 
dan Liu (2009) yang menemukan bahwa perusahaan dengan kepemilikan saham terkonsentrasi akan cenderung memilih auditor yang berasal dari non-Top 10 .

Namun demikian, kondisi konflik keagenan yang dapat menurunkan nilai perusahaan dan meningkatkan cost of capital akan menyulitkan pemegang saham pengendali untuk memperoleh pendanaan dari luar (El Ghoul et al., 2007). Dalam kondisi tersebut, pemegang saham pengendali akan lebih termotivasi untuk menunjuk auditor eksternal yang berkualitas tinggi dalam rangka mengurangi potensi konflik keagenan akibat negative entrenchment effect (Fan dan Wong, 2005). Selain itu penunjukan auditor eksternal yang berkualitas tinggi juga dapat dipandang sebagai suatu sinyal bahwa pemegang saham pengendali melindungi dan memperhatikan kepentingan pemegang saham nonpengendali. Dengan demikian, berdasarkan latar belakang di atas memicu timbulnya pertanyaan apakah di Indonesia, yang sebagian besar terkonsentrasi pengendalian perusahaan pada keluarga, hal ini akan berpengaruh positif atau negatif terhadap keputusan pemilihan kantor akuntan publik.

Dengan kendali terbesar yang dimiliki oleh pihak keluarga, pihak keluarga akan menempatkan dirinya ataupun anggota keluarganya sebagai pimpinan utama perusahaan (Peng dan Jiang, 2010). Berdasarkan penelitian yang dilakukan oleh Claessens et al. (2000), hampir sebagian besar perusahaan yang dikendalikan oleh keluarga di Asia, direktur utama dari sekitar $60 \%$ perusahaan yang kepemilikannya terkonsentrasi pada keluarga, merupakan orang yang memiliki hubungan keluarga dengan pengendali perusahaan. Penempatan anggota keluarga pada posisi pimpinan utama perusahaan merupakan suatu usaha atau strategi untuk menyelaraskan tujuan keluarga sebagai pemegang saham pengendali dengan manajemen perusahaan
(Anderson dan Reeb, 2003; Peng dan Jiang, 2010). Dan hal ini tentunya akan mempengaruhi dampak pengendalian oleh pihak keluarga terhadap kinerja perusahaan tersebut (Peng dan Jiang, 2010; Chung dan Chan, 2012). Pengendalian pihak keluarga yang diperoleh melalui mekanisme kepemilikan langsung dan tidak langsung berdampak positif lebih besar ketika pimpinan utama perusahaan tersebut adalah pendiri (founders) dari perusahaan yang dikendalikannya (Anderson dan Reeb, 2003) dibandingkan jika CEO (Direktur utama perusahaan) bukan pendiri perusahaan. Pendiri (founder) akan memiliki socioemotional wealth yang lebih tinggi dan rasa kepemilikan yang tinggi sehingga akan mendorong mereka menjaga kesinambungan usaha perusahaan (Anderson dan Reeb, 2003).

Untuk membatasi tindakan ekspropriasi oleh pemegang saham pengendali diperlukan ketentuan pasar modal serta mekanisme tata kelola perusahaan (corporate governance-CG) yang memadai. Dewan komisaris memiliki peranan penting dalam menjalankan fungsi pengawasan dan memastikan bahwa perusahaaan telah melaksanakan GCG (good corporate governance). Pengawasan yang dilakukan oleh dewan komisaris harus dapat menjamin terlindunginya hak-hak para pemangku kepentingan termasuk kepentingan pemegang saham.

Fungsi pengawasan yang dilakukan oleh Dewan Komisaris juga ditingkatkan melalui penerbitan Peraturan Otoritas Jasa Keuangan No. 33/POJK.04/2014 tentang Direksi dan Dewan Komisaris Emiten pada Perusahaan Publik. Dalam peraturan tersebut, komposisi dewan komisaris pada perusahaan publik harus memiliki anggota Dewan Komisaris Independen yang berjumlah minimal sebesar $30 \%$ dari jumlah dewan komisaris perusahaan. Kehadiran dewan komisaris independen diharapkan dapat meningkatkan efektifitas fungsi pe- 
ngawasan oleh Dewan Komisaris terhadap Dewan Direksi. Keefektifan fungsi Dewan Komisaris melakukan pengawasan terhadap perusahaan diharapkan mampu mendorong auditor untuk meningkatkan kua litas auditnya.

Penelitian ini penting dilakukan di Indonesia mengingat struktur kepemilikan di Indonesia sebagian besar terkonsentrasi dan didominasi oleh kepemilikan keluarga. Diyanty (2012) dan Ulupui (2009) menemukan ada $88 \%$ perusahaan publik yang dimiliki keluarga dan menempatkan keluarga pada posisi direksi dan komisaris. Temuan ini mendukung penelitian sebelumnya oleh Lukviarman (2004) yang menyatakan bahwa $80 \%$ perusahaan di Indonesia mengalami campur tangan keluarga baik dalam posisi manajemen maupun komisaris. Adanya dominasi kepemilikan pengendali oleh keluarga memicu konflik keagenan yang tinggi antara pengendali keluarga dan pemegang saham non pengendali. Adanya dominasi kepemilikan keluarga pengendali yang tinggi melalui kepemilikan struktur piramida mendorong terjadinya motivasi untuk melakukan ekspropriasi (diyanty, 2012). Untuk menutupi tindakan ekspropriasi serta menjaga reputasi perusahaan, pemegang saham pengendali cenderung untuk memilih auditor yang berkualitas.

Hasil penelitian ini diharapkan dapat menjadi acuan bagi regulator untuk meningkatkan perannya dalam: (i) meningkatkan pengawasan di pasar modal melalui aturan-aturan dalam penerapan good corporate governance dan aturan untuk meningkatkan keefektifan Peran dari Dewan Komisaris; (ii) meningkatkan mekanisme pengawasan dalam rangka memberikan perlindungan kepada investor dan pemegang saham non-pengendali; (iii) pertimbangan untuk mendorong dikeluarkannya kebijakan tentang pengungkapan rantai kepemilikan pengendali akhir dalam laporan keuangan. Pengungkapan rantai kepemilikan ultimate (akhir) dalam pengungkapan laporan keuangan diharapkan akan memberikan gambaran pemegang saham pengendali terbesar di perusahaan apakah kendali yang diperolehnya melalui kepemilikan langsung atau melalui kepemilikan piramida.

Berdasarkan penjelasan diatas perumusan masalah dalam penelitian ini adalah sebagai berikut (1) Apakah pengendalian keluarga melalui mekanisme kepemilikan langsung dan piramida berpengaruh terhadap kualitas audit? (2) Apakah pendiri perusahaan yang menjadi pimpinan utama perusahaan akan berpengaruh terhadap kualitas audit? (3) Apakah efektivitas dewan komisaris berpengaruh terhadap kualitas audit?

Penelitian ini dilakukan atas perusahaan nonkeuangan yang terdaftar di Bursa Efek Indonesia selama periode 2010 hingga 2013. Pemilihan periode tersebut sehubungan dengan kesulitan kembali untuk memperoleh data terbaru di DEPHUMKAM dengan biaya yang relative mahal untuk penelusuran kepemilikan perusahaan non publik. Pemilihan industry keuangan disebabkan Industri keuangan memiliki karakteristik dan kompleksitas transaksi yang berbeda dari industri non keuangan yang membutuhkan keahlian dan kompetensi spesifik industri keuangan dari sisi auditor yang mungkin tidak dimiliki oleh semua kantor akuntan publik. Karena itu penelitian ini hanya mengkaji sampel perusahaan nonkeuangan untuk mengontrol faktor kompetensi auditor atas industri keuangan yang dapat mempengaruhi pilihan kantor akuntan publik oleh perusahaan.

\section{TINJAUAN TEORETIS \\ Struktur Kepemilikan dan Konflik Keagenan}

Konflik keagenan antara pemegang saham dengan manajemen timbul pada negara dengan karakteristik struktur kepemilikan tersebar seperti AS dan Inggris (Jensen dan Meckling, 1976). Beberapa penelitian terdahulu mengemukakan bahwa dalam struktur kepemilikan perusahaan 
yang sangat terkonsentrasi seperti banyak terjadi Asia (termasuk Indonesia), masalah keagenan yang terjadi adalah bukan lagi antara manajemen dengan pemegang saham, melainkan antara pemegang saham pengendali (sebagai agen) dan manajemen, terhadap pemegang saham non-pengendali (La Porta et al., 1999; Claessens et al., 1999b; dan Diyanty, 2012). Pada struktur kepemilikan yang terkonsentrasi, manajemen merupakan representasi pemegang saham pengendali.

Pengendalian terhadap sebuah perusahaan dapat diperoleh melalui dua mekanisme kepemilikan, yaitu mekanisme kepemilikan langsung dan mekanisme kepemilikan struktur piramida (La Porta et al., 1999; Claessens et al., 2000). Pengendalian melalui mekanisme kepemilikan langsung diperoleh dengan cara investasi sejumlah saham langsung pada sebuah perusahaan (La Porta et al., 1999). Dengan mekanisme kepemilikan langsung, hak kendali yang dimiliki oleh pemegang saham adalah sejumlah investasi yag ditanamkan pada perusahaan sehingga tidak akan terjadi perbedaan antara hak arus kas dan hak kendali pemegang saham. Semakin tinggi investasi yang dilakukan semakin tinggi komitmen pemegang saham pengendali untuk meningkatkan nilai perusahaan. Kondisi ini disebut dengan efek alignment.

Hak aliran kas merupakan klaim keuangan pemegang saham atas investasinya terhadap perusahaan. Sedangkan hak kontrol adalah hak suara (voting) untuk ikut serta dalam pengambilan keputusan dalam menentukan kebijakan perusahaan. Hak pengendalian yang diperoleh melalui mekanisme kepemilikan piramida diperoleh melalui serangkaian rantai kepemilikan pada perusahaan lain (Almeida dan Wolfenzon, 2006). Pengendalian melalui mekanisme piramida merupakan rangkaian kepemilikan yang kompleks dan memungkin kan hak suara yang dimiliki oleh pengendali melebihi hak arus kasnya (Chung dan
Chan, 2012). Pada penelitian sebelumnya, Claessens et al. (1999b) dan Diyanty (2012) mengungkapkan bahwa $71,5 \%$ perusahaan di Indonesia dikendalikan oleh keluarga, di mana $66,9 \%$ pemegang saham pengendali cenderung memiliki hak suara atau hak kendali yang melebihi hak aliran kas, dimana hak suara ini diperoleh melalui mekanisme struktur kepemilikan piramida. Melalui mekanisme struktur kepemilikan piramida, pemegang saham pengendali memiliki pengendalian langsung pada perusahaan, dan pada saat bersamaan juga mengontrol perusahaan lain yang pada akhirnya membentuk cara yang paling umum dalam mengendalikan pemegang saham non pengendali dengan memisahkan hak kendali dari hak aliran kas (Claessens et al., 2000; Faccio dan Lang, 2002). Kondisi hak kendali yang melebihi hak aliran kas berpotensi menyebabkan negative entrenchment melalui tindakan-tindakan yang dapat merugikan pemegang saham non-pengendali melalui manajemen (Shleifer and Vishny, 1986).

Pemisahan kepemilikan dan kontrol lebih terlihat pada perusahaan yang dikontrol oleh keluarga dan perusahaan berskala kecil. Claessens et al. (2000) menyimpulkan ketika terjadi perbedaan yang cukup besar antara hak kendali dan hak aliran kas (wedge), melalui mekanisme struktur kepemilikan piramida, dan ketika pemegang saham pengendali terbesar adalah keluarga, maka tingkat ekspropriasi terhadap pemegang saham non-pengendali menjadi lebih tinggi.

Salah satu cara untuk menghilangkan masalah entrenchment dari pemegang saham pengendali adalah meningkatkan kepemili kan saham dari pemegang saham pengendali atau bahkan melalui go private. Makin tingginya kepemilikan saham (hak aliran kas) oleh pemegang saham pengendali cenderung memberikan komitmen dan meningkatkan alignment kepentingan antara pemegang saham pengendali dan pe- 
megang saham non-pengendali (Gomes, 2000). Hal ini disebut alignment effect (Fan dan Wong, 2002) atau Positive Incentive Effect (Yeh, 2005).

Almeida dan Wolfenzon (2006) dalam hasil penelitiannya menyimpulkan konsekuensi atas perolehan pengendalian melalui mekanisme struktur kepemilikan piramida. Pertama, perusahaan-perusahaan yang ada dalam struktur kepemilikan piramida berada pada industri yang berbeda dengan perusahaan pengendali. Kedua, nilai dan kinerja perusahaan afiliasi yang dikendalikan melalui kepemilikan piramida lebih rendah daripada perusahaan-perusahaan non afiliasi. Disamping itu hasil penelitian juga menunjukkan bahwa grup bisnis keluarga umumnya berada pada negara yang memiliki proteksi yang lemah terhadap investor. Ketika perusahaan baru ditambahkan ke dalam struktur piramida, maka pemegang saham non-keluarga yang ada akan mengalami pengembalian (return) negatif.

\section{Perusahaan Keluarga}

Penelitian sebelumnya mendefinisikan perusahaan keluarga sebagai kepemilikan keluarga, pengendalian terhadap hak suara, keterlibatan keluarga dalam manajemen, pengendalian terhadap pemilihan direksi dan komisaris (Chua et al., 1999; GómezMejía et al., 2007; Liu et al., 2010). Diyanty (2012) menyatakan bahwa suatu perusahaan keluarga meruapakan perusahaan dimana pengendali akhir terbesar merupakan suatu keluarga (baik individu ataupun sekelompok orang yang memiliki hubungan darah dan hubungan perkawinan) baik melalui mekanisme kepemilikan langsung maupun melalui mekanisme kepemilikan piramida serta adanya keterlibatan keluarga yang ikut serta dalam manajemen perusahaan.

Keterlibatan pendiri perusahaan atau anggota keluarga pendiri sebagai manajemen utama perusahaan merupakan strategi yang dilakukan oleh pendiri perusaha- an (founder) ataupun keluarga pendiri untuk meningkatkan pengendaliannya terhadap perusahaan (Peng dan Jiang, 2010). Semakin besar hak kendali yang dimiliki keluarga, semakin besar power dari keluarga untuk menyelaraskan tujuan pribadi keluarga dengan manajemen perusahaan dimana manajemen perusahaan merupakan representasi dari keluarga. Kondisi ini diperburuk jika pengendalian tersebut diperoleh melalui mekanisme kepemilikan piramida dimana hak kendali melebihi hak arus kas sehingga meningkatkan konflik keagenan antara pihak keluarga pengendali perusahaan dengan pemegang saham non pengendali, melalui mekanisme ekspropriasi pemegang saham pengendali (negative entrenchment effect). Hal ini dapat terjadi karena anggota keluarga yang menjadi top management perusahaan memiliki akses yang luas terhadap pemanfaatan sumber daya perusahaan. Disamping itu pengendalian keluarga memiliki investment horizon yang lebih luas sehingga hal ini akan memberikan keuntungan bagi perusahaan (Liu et al., 2010; James, 1999).

Namun demikian kondisi ini akan berbeda pada saat pendiri atau anggota keluarga pendiri memperoleh pengendalian melalui mekanisme kepemilikan langsung, dimana keluarga akan mempertahankan socioemotial wealth yang dimilikinya dengan berusaha untuk menjaga kesinambungan usaha perusahaan (Gómez-Mejía et al., 2007). Dengan demikian, semakin tinggi kepemilikan pemegang saham pengendali keluarga melalui mekanisme langsung maka semakin tinggi motivasi pemegang saham untuk meningkatkan kinerja perusahaan. Dengan menempatkan anggota keluarga sebagai top management perusahaan maka akan semakin mudah pemegang saham pengendali mengambil kebijakan strategis perusahaan dalam rangka meningkatkan kinerja perusahaan (alignment effect) salah satunya akan semakin mendorong untuk memilih Auditor yang berkualitas . 


\section{Kualitas Audit}

Investor memiliki perspektif sendiri terhadap audit. Investor ingin agar laporan keuangan yang mereka gunakan dapat digunakan untuk pengambilan keputusan. Agar dapat digunakan untuk pengambilan keputusan, laporan keuangan tersebut haruslah memiliki kredibilitas tinggi, sehingga investor menilai kualitas audit dari kredibilitas laporan keuangan. Investor akan melihat siapa yang menyusun laporan keuangan tersebut dan auditor yang memberikan opini atas laporan keuangan tersebut. Investor akan memiliki ekspektasi perusahaan yang diaudit oleh auditor yang memiliki reputasi baik akan menghasilkan laporan keuangan yang kredibel.

Dari sisi komite audit yang mengawasi proses audit, penilaian mengenai kualitas audit bisa juga berasal dari reputasi auditor eksternal, kualitas dari proses audit yang dijalankan auditor eksternal, serta komunikasi dan interaksi auditor eksternal dengan manajemen.

Konsep awal mengenai kualitas audit dihubungkan dengan independensi auditor. Menurut DeAngelo (1981), independensi auditor didefinisikan sebagai kemungkinan bahwa auditor akan menemukan dan melaporkan salah saji dalam laporan keuangan serta tidak mengindahkan tekanan dari manajemen untuk tidak melaporkan salah saji tersebut (jika terdapat tekanan dari manajemen).

Kualitas audit juga bisa dilihat dari sisi kegagalan audit. Kegagalan audit sulit didefinisikan, namun menurut Francis (2004) dapat diukur dari berbagai sumber seperti tuntutan terhadap auditor, kegagalan bisnis, pemeriksaan oleh otoritas pasar modal, dan penyajian kembali laporan keuangan. Semakin tinggi kualitas audit, tentunya kegagalan audit akan semakin berkurang.

Ukuran auditor juga digunakan sebagai ukuran kualitas audit. DeAngelo (1981) berpendapat bahwa kantor auditor yang besar memiliki kualitas audit yang lebih baik karena tidak ada ketergantungan terhadap klien tertentu sehingga auditor memiliki independensi yang lebih tinggi. Terinspirasi oleh studi tersebut, penelitian yang berfokus pada Big $\mathrm{N}$ berpendapat bahwa Big $\mathrm{N}$ telah memiliki reputasi dan memiliki insentif untuk memberikan jasa audit yang berkualitas tinggi untuk menjaga reputasinya. Becker et al. (1998) dan Francis et al. (1999) membuktikan bahwa perusahaan yang diaudit KAP Big 4 memiliki akrual abnormal yang lebih rendah, yang berarti manajemen laba yang lebih rendah dan kualitas laba yang lebih tinggi.

Kualitas audit Big 4 menurut beberapa penelitian mungkin berasal dari biaya audit yang lebih tinggi dan keahlian khusus dalam industri (Simunic, 1980).

menemukan bahwa KAP Big 4 memiliki biaya audit yang lebih tinggi (fee premium) daripada KAP-KAP lainnya setelah mengontrol karakteristik klien seperti ukuran, kompleksitas dan pembagian risiko antara auditor dan klien. Secara ratarata biaya audit Big 4 diestimasi lebih tinggi $20 \%$ daripada non-Big 4 . Biaya audit yang lebih tinggi diharapkan meningkatkan kualitas audit karena berarti usaha audit yang lebih tinggi, ditandai dengan jam kerja audit yang tinggi atau berasal dari kemampuan auditor yang lebih tinggi (Francis, 2004).

Jika suatu KAP memiliki banyak klien dalam industri tertentu, tentunya mereka akan memiliki kesempatan untuk mengembangkan kemampuan dan memperoleh pengalaman sehingga menjadi ahli dalam industri tersebut. KAP Big4 memiliki klien yang banyak di berbagai industri dan memiliki sumber daya untuk mengembangkan keahlian auditornya, sehingga Big4 lebih mungkin mengembangkan keahlian industri dibandingkan KAP non-Big 4 . Balsam et al. (2003) menemukan bahwa klien yang diaudit KAP Big4 dan memiliki spesialisasi industri memiliki akrual dis- 
kresioner yang lebih rendah dan koefisien respons laba yang lebih tinggi, menggambarkan kualitas laba yang tinggi.

Dari penjelasan diatas di atas, dapat disimpulkan bahwa kualitas audit memiliki sifat multidimensi dan tidak memiliki satu ukuran karakteristik tertentu yang dapat menggambarkan kualitas audit secara menyeluruh (Bamber dan Bamber, 2009; Francis, 2004; dan Watkins et al., 2004).

\section{Dewan Komisaris}

Dewan komisaris bertugas melakukan pengawasan dan memberikan nasihat kepada dewan direksi. Dalam menjalankan fungsi pengawasan, Dewan komisaris bertugas mengawasi kinerja Direksi dan manajemen agar dalam pelaksanaan tugasnya sesuai dengan kepentingan pemegang saham baik pemegang saham pengendali maupun non pengendali. Namun di samping itu, Dewan Komisaris juga berfungsi memberikan saran dan rekomendasi atas keputusan manajemen dalam rangka meningkatkan kinerja manajemen (UU PT No 40 Tahun 2007). Keefektifan tugas Dewan Komisaris akan memberikan manfaat bagi perusahaan jika memberikan keuntungan terhadap perusahaan.

Kehadiran Dewan Komisaris di dalam organ perusahaan merupakan bentuk kepatuhan perusahaan terhadap prinsip OECD yang keenam. OECD memiliki enam prinsip tata kelola perusahaan, yaitu 1) Menjamin kerangka dasar tata kelola perusahaan yang efektif; 2) Menjamin hakhak pemegang saham dan fungsi-fungsi penting dalam kepemilikan; 3) Perlakuan yang adil terhadap seluruh pemegang saham; 4) Peranan para pemangku kepentingan dalam tata kelola perusahaan; 5) Pengungkapan dan transparansi; 6) Tanggung jawab Dewan Direksi dan Dewan Komisaris

Prinsip OECD yang keenam membahas mengenai tanggung jawab Dewan Komisaris. Prinsip terakhir dari OECD ini menyatakan bahwa tata kelola perusahaan yang baik harus menjamin tersedianya pedoman strategis untuk perusahaan, dan pengawasan yang efektif terhadap manajemen oleh Dewan Komisaris.

\section{Pengembangan Hipotesis dan Model Empiris Penelitian Pengaruh Pengendali Keluarga pada Kualitas Audit}

Auditor eksternal yang independen merupakan penjaga pintu gerbang pasar modal untuk melindungi kepentingan publik dengan memverifikasi informasi keuangan yang dibuat oleh manajemen perusahaan. Dalam kaitannya dengan fungsi sebagai pemberi keyakinan (assurance) ini maka tuntutan audit yang berkualitas menjadi mengemuka. Kualitas audit merupakan konsep yang didefinisikan sebagai "the market assessed joint probability that a given auditor will both (a) discover a breach in the client's accounting system, and (b) report the breach" (DeAngelo, 1981). Ada dua komponen penting dalam definisi ini. Pertama, faktor probabilitas auditor untuk menemukan pelanggaran (baik berupa kesalahan maupun kecurangan) pada sistem akuntansi klien. Menurut Watts dan Zimmerman (1986), hal ini tergantung pada kompetensi atau kemampuan dari auditor. Kedua, faktor probabilitas auditor untuk melaporkan pelanggaran tersebut, yang tergantung pada kesediaan (independensi) auditor untuk melaporkan atau mengkoreksi praktik pelaporan yang ada.

Kualitas audit merupakan konsep yang abstrak dan sulit diobservasi sehingga kemudian dikembangkan beberapa proksi untuk mengukurnya. Beberapa proksi yang umumnya digunakan pada penelitianpenelitian terdahulu adalah ukuran KAP (Becker et al. 1998; Reynolds dan Francis 2000), spesialisasi industri (Balsam et al., 2003), dan audit tenure yakni lamanya masa penugasan audit/pengalaman KAP (Ghosh dan Moon, 2005). Determinan-determinan ini mencerminkan faktor-faktor yang dapat memengaruhi kemampuan atau kompetensi auditor dalam menemukan praktik pelanggaran pelaporan keuangan. Sedangkan 
faktor-faktor yang memengaruhi kesediaan auditor untuk melaporkan atau mengkoreksi pelanggaran yang ditemukan misalnya kepentingan KAP terhadap klien (client importance), pengaruh praktik perusahaan dalam memenuhi target laba, praktik corporate governance, kecenderungan untuk menerbitkan opini audit going concern, peer review yang dilakukan, dan ukuran independensi lainnya (Bamber dan Bamber, 2009).

Penelitian-penelitian tentang kualitas audit di Indonesia juga lebih banyak menggunakan pengukuran tunggal seperti ukuran KAP yang berafiliasi dengan Big 4 (Siregar dan Utama 2006; 2008) atau spesialisasi industri KAP (Mayangsari, 2004). Penelitian ini menggunakan proksi kualitas audit ukuran KAP yang berafiliasi dengan Big 4 (Siregar dan Utama 2006; 2008) untuk mengkaji pengaruh pengendali keluarga terhadap pertimbangan pemilihan auditor berdasarkan kualitasnya.

KAP besar (saat ini Big 4) memiliki pengetahuan, pengalaman teknis, kapasitas, dan reputasi yang lebih baik dibandingkan KAP yang lebih kecil (Bloom dan Schirm, 2008), sehingga diduga dapat menghasilkan kualitas audit yang lebih tinggi. Menurut DeAngelo (1981), kualitas audit yang lebih tinggi ini disebabkan adanya ekspektasi bahwa auditor dari KAP besar tidak melakukan kompromi dalam independensi atau menunjukkan perilaku oportunis yang bisa menyebabkan hilangnya kredibilitas pada penugasan audit lainnya. Beberapa penelitian terdahulu menemukan hubungan positif kualitas audit yang diproksi dengan reputasi dan ukuran KAP dengan kualitas laba, yang mengindikasikan bahwa KAP besar lebih memiliki kemampuan untuk mendeteksi manajemen laba sehingga bisa dikatakan memiliki kualitas audit yang lebih tinggi (Becker et al., (1998); Francis et al., (1999); dan Reynolds dan Francis, (2000)). Francis dan Yu (2009) memberikan bukti yang konsisten bahwa KAP Big 4 lebih cenderung untuk menerbitkan opini goingconcern dan klien KAP Big4 juga menunjukkan tingkat manajemen laba yang lebih rendah.

Dalam kaitannya dengan pengendali keluarga, Lin dan Liu (2009) menggunakan ukuran KAP sebagai proksi kualitas audit. Perusahaan umumnya menghadapi trade-off dalam kebijakan pemilihan auditor. Pilihan yang harus diambil adalah antara memilih auditor berkualitas tinggi untuk memberikan sinyal pengawasan audit dan tata kelola perusahaan yang efektif sehingga bisa menurunkan biaya modal atau memilih auditor berkualitas rendah untuk mengambil keuntungan dari lemahnya tata kelola dan pengungkapan yang kurang transparan (yang disebut juga sebagai manfat "kekaburan" atau opaqueness gains).

Lin dan Liu (2009) mengklasifikasikan semua auditor di Cina ke dalam auditor Top-10 dan selainnya (non-Top 10), dan mengasumsikan bahwa auditor top 10 dapat memberikan jasa audit berkualitas tinggi. Konsentrasi kepemilikan merupakan salah satu variabel pada penelitian ini yang mencerminkan mekanisme tata kelola perusahaan. Hasil penelitian empiris menemukan bahwa perusahaan dengan kepemilikan saham terkonsentrasi lebih memilih auditor yang berasal dari non-Top 10 . Hal ini mengindikasikan bahwa perusahaan dengan mekanisme tata kelola yang lebih lemah cenderung mempertahankan opaqueness gains.

Darmadi (2016) mengevaluasi pemilihan auditor dengan menggunakan perusahaan public di Indonesia selama tahun 20052007 dan menemukan bahwa perusahaan dengan konsentrasi kepemilikan yang lebih tinggi cenderung untuk memilih auditor Big4. Namun, ketika pemegang saham pengendali merupakan keluarga, penelitian Darmadi (2016) menunjukkan bahwa asosiasi antara konsentrasi kepemilikan dan kebutuhan akan auditor yang berkualitas menjadi negatif yang artinya perusahaan 
yang dikendalikan oleh keluarga cenderung untuk mempertahankan opaqueness laporan keuangannya dengan cara memilih auditor dengan kualitas yang lebih rendah. Namun demikian, kajian Kang (2014) atas 1500 perusahaan Standard \& Poor's (S\&P) menunjukkan bahwa perusahaan keluarga memiliki insentif yang besar untuk memberikan sinyal kepada public bahwa laporan keuangan mereka berkualitas tinggi.

Konsentrasi kepemilikan pada keluarga yang diperoleh melalui kepemilikan langsung berdampak pada jumlah hak arus kas dan hak kendali yang diperoleh sebesar jumlah investasi yang ditanamkan pada perusahaan. Semakin tinggi hak kendali yang diperoleh dari kepemilikan langsung menandai semakin tingginya jumlah investasi yang ditanamkan perusahaan. Kondisi tersebut mendorong pemegang saham pengendali untuk menyelaraskan kepentingan pemegang saham pengendali dengan pemegang saham non pengendali (efek alignment). Kepemilikan terkonsentrasi juga dapat menyebabkan hal sebaliknya, yakni dapat memotivasi pemegang saham pengendali untuk menyelaraskan kepentingan nya (efek alignment) dengan perusahaan atau pemegang saham non-pengendali.

Hak kendali yang tinggi melalui kepemilikan langsung mengimplikasikan bahwa pemegang saham akan melakukan pengawasan yang lebih efektif terhadap perusahaan karena pemegang saham pengendali cenderung melepaskan manfaat jangka pendek untuk menjaga reputasi keluarga dan untuk mewariskan bisnis yang berkelanjutan kepada pewarisnya (alignment effect). Dengan demikian, hipotesis pertama penelitian ini adalah sebagai berikut:

$\mathrm{H}_{1}$ : Semakin tinggi hak kendali keluarga melalui kepemilikan langsung, semakin tinggi kecenderungan memilih auditor yang berkualitas.

Namun demikian jika hak kendali terbesar diperoleh melalui mekanisme kepemilikan piramida, kondisi tersebut akan menyebabkan jumlah hak kendali melebihi hak arus kas. Dalam kondisi ini pemegang saham pengendali akan cenderung menggunakan hak kendalinya untuk mempertahankan "kekaburan" (opacity) dibandingkan transparansi yang memicu dipilihnya auditor berkualitas rendah untuk mempertahankan kondisi tersebut.

Senada dengan Lin dan Liu (2009), Khan et al., (2011) juga menemukan hasil serupa untuk konteks Bangladesh yang juga didominasi perusahaan publik yang dimiliki keluarga. Untuk konteks Indonesia, Darmadi (2016) juga menemukan bahwa perusahaan yang mayoritasnya dimiliki keluarga cenderung memilih KAP bukan Big 4 dan perusahaan keluarga cenderung menjaga opaqueness dengan memilih auditor berkualitas rendah.

Kendali keluarga yang melebihi aliran kas di tangan pemegang saham pengendali memungkinkan terjadinya ekspropriasi sumber daya perusahaan dengan mengorban kan kepentingan pemegang saham minoritas (efek entrenchment). Hal ini diprediksi dapat menurunkan kualitas pelaporan keuangan melalui pemilihan auditor berkualitas rendah oleh pemegang saham pengendali untuk mengurangi pengawasan atas tindakan ekspropriasi yang dilakukan (Lin dan Liu, 2009). Pada akhirnya hal ini juga mencerminkan efek entrenchment dari kepemilikan keluarga sehingga hipotesis kedua dikembangkan sebagai berikut:

$\mathrm{H}_{2}$ : Semakin tinggi hak kendali keluarga melalui kepemilikan piramida, semakin rendah kecenderungan memilih auditor yang berkualitas .

Dalam suatu perusahaan dengan hak kendali terbesar melalui kepemilikan langsung, penempatan pendiri perusahaan pada posisi top management, akan makin menyelaraskan kepentingan manajemen dengan kepentingan pemegang saham pengendali dalam mempertahankan socioemotional wealth agar terjaga kesinambungan 
perusahaan (alignment effect). Berdasarkan argumen tersebut diduga dengan menempatkan keluarga sebagai bagian dari top management akan memperkuat alignment effect sehingga tercapai keselarasan tujuan pemegang saham pengendali dengan non pengendali. Sedangkan penempatan pendiri perusahaan sebagai pimpinan utama perusahaan pada perusahaan dimana pihak keluarga merupakan pengendali terbesar melalui mekanisme kepemilikan piramida akan menimbulkan negative entrenchment effect. Pihak keluarga termotivasi untuk melakukan memilih auditor yang berkualitas rendah untuk menutupi dampak ekspropriasi yang dilakukanya. Dengan demikian hipotesis ketiga adalah sebagai berikut:

$\mathrm{H}_{3}$ : Pendiri perusahaan sebagai pimpinan utama perusahaan berkecenderungan memiilih auditor yang berkualitas tinggi

Efek alignment dari pemegang saham pengendali (Darmadi, 2016; Hay et al., 2008) berpengaruh positif terhadap kualitas audit. Tata kelola perusahaan yang efektif juga terbukti meningkatkan kualitas audit (Maharani, 2011; Putra, 2015; Lin dan Liu, 2009). Diyanty (2012) menyebutkan bahwa bahwa praktik tata kelola perusahaan yang kuat dapat melemahkan efek negatif dari entrenchment pemegang saham pengendali terhadap besaran transaksi pihak berelasi dan kualitas laba. Penemuan Diyanty (2012) tersebut membuat peneliti menduga bahwa tata kelola perusahaan juga dapat memoderasi efek alignment dari pemegang saham pengendali. Karena efek alignment pemegang saham pengendali berpengaruh positif terhadap kualitas audit, dan tata kelola perusahaan juga berpengaruh positif terhadap kualitas audit, peneliti menduga bahwa efek alignment pemegang saham pengendali terhadap tingkat kualitas audit akan semakin kuat jika terdapat tata kelola perusahaan yang efektif. Hipotesis yang diajukan berdasarkan dugaan itu adalah sebagai berikut:

$\mathrm{H}_{4}$ : Semakin tinggi efektivitas Dewan Komisaris semakin tinggi kecenderungan memilih auditor yang berkualitas tinggi

\section{METODE PENELITIAN \\ Kerangka Pemikiran dan Jenis Riset Jenis dan Sumber Data}

Data yang digunakan dalam penelitian ini merupakan data sekunder, berupa data struktur kepemilikan perusahaan, baik yang langsung maupun yang tidak langsung, data pemimpin keluarga yang ada di dalam perusahaan, data mengenai dewan komisaris, kinerja perusahaan baik kinerja akuntansi maupun kinerja pasar, data auditor, perpajakan, utang bank dan utang public serta berbagai data variabel kontrol lainnya. Data-data tersebut didapatkan dari berbagai sumber.

Untuk menelusuri kepemilikan keluarga di suatu perusahaan, peneliti menggunakan laporan tahunan perusahaan yang didapat dari Thomson Reuters Eikon sebagai sumber utama, dan dilanjutkan dengan menelurusi website Bursa Efek Indonesia dan website perusahaan untuk mencari laporan tahunan perusahaan. Terdapat beberapa laporan tahunan perusahaan yang mengungkapkan pengendali utamanya (ultimate owner), dan untuk laporan tahunan yang tidak mengungkapkan pemilik utamanya peneliti menggunakan data yang diambil dari Departemen Administrasi Hukum Umum, Kementrian Hukum dan HAM Republik Indonesia untuk menelusuri pemilik utama dari perusahaan tersebut. Selain itu dari laporan tahunan perusahaan didapatkan juga data pemimpin perusahaan, efektivitas dewan komisaris, dan juga umur perusahaan. Untuk menentukan apakah pimpinan utama perusahaan tersebut merupakan pendiri atau anggota keluarga pengendali perusahaan, digunakan data hubungan 
keluarga yang ada pada penelitian Diyanty (2012). Untuk data auditor diperoleh data P2PK (Pusat Pembinaan Profesi Keuangan). Kemudian peneliti menggunakan Data Stream Professional dari Thomson Reuters untuk mendapatkan data kinerja perusahaan dan data variabel kontrol lainnya.

\section{Populasi dan Metode Sampling}

Populasi untuk penelitian ini adalah semua perusahaan yang terdaftar di Bursa Efek Indonesia untuk period tahun 2009 sampai dengan 2013. Metode pemilihan sampel adalah purposive sampling dengan kriteria perusahaan adalah sebagai berikut:

1. Perusahaan berada dalam industri non keuangan

2. Perusahaan memiliki laporan keuangan tahunan yang berakhir setiap tanggal 31 Desember.

3. Perusahaan tidak memiliki ekuitas negatif selama periode pengamatan.

4. Perusahaan terdaftar di BEI selama periode penelitian yaitu tahun 2009 sampai dengan 2013 (tidak pernah delisting, suspensi tahunan, atau go private) selama periode penelitian.

5. Perusahaan tidak terlibat dalam corporate control action, seperti merger, akuisisi, divestasi selama periode penelitian.

6. Perusahaan non perusahaan BUMN.

7. Perusahaan yang tidak dimiliki oleh perusahaan asing yang kepemilikannya tidak dapat ditelusuri.

8. Perusahaan yang kepemilikan saham pengendalinya bukan masuk kategori Asing tapi Indonesia (ASTINDO).

Perusahaan yang termasuk dalam kategori ASTINDO adalah perusahaan dengan kepemilikan akhirnya adalah asing tapi sebenarnya masih dikendalikan oleh keluarga Indonesia (ASTINDO). Krisis ekonomi pada tahun 1997 dan 1998 menyebabkan struktur kepemilikan perusahaan-perusahaan di Indonesia banyak yang mengalami perubahan diantaranya beberapa perusahaan mengalami restrukturi- sasi atau merger. Dalam proses perubahan struktur kepemili- kan, pemilik lama yang pernah mengontrol perusahaan sebelum krisis dilarang untuk memegang kembali perusahaan tersebut. Namun dengan berbagai cara, pemilik lama dapat memegang kembali perusahaan mereka setelah direstrukturisasi (Suk, 2006). Misalkan Indofood yang dimiliki oleh grup Salim sebelum krisis, pada tahun 1999 menjadi PMA yang dimiliki oleh First Pasific dan Nissin. Namun First Pasific sebenarnya dimiliki oleh kelompok usaha Salim yang berpusat di Hong Kong (Kompas, 26 Januari, 1999).

Pemilik lama kemungkinan besar membeli saham atas nama orang asing untuk mengontrol kembali perusahaan yang mereka miliki. Perusahaan asing tersebut kemungkinan didirikan di negaranegara seperti British Virgin Island atau Mauritius yang tidak mewajibkan perusahaan untuk melaporkan sumber dana dan struktur kepemilikan (Suk, 2006).

Dalam hal ini perusahaan yang memenuhi kriteria tersebut akan dinamakan ASTINDO dan akan dikeluarkan dari sampel penelitian. ASTINDO diidentifikasi berdasarkan data dari Pusat Data Bisnis Indonesia, di mana perusahaan yang pada awal pendiriannya dimiliki oleh keluarga, dan setelah di awal tahun 2000-an mengalami perubahan kepemilikan menjadi institusi asing dan masih tetap dikendalikan oleh orang yang sama berdasarkan informasi dari data PDBI, maka akan dikate gorikan sebagai ASTINDO.

\section{Model Penelitian}

Adapun model untuk menguji pengaruh pengendali keluarga terhadap kualitas audit adalah sebagai berikut:

$\mathrm{AQ}_{\mathrm{it}}=\alpha+\beta_{1} \mathrm{D}-\mathrm{O} w n_{\mathrm{it}}+\beta_{2} \mathrm{P}-\mathrm{O} \mathrm{wn}_{\mathrm{it}}+\beta_{3} \mathrm{Fam}-$ $\mathrm{CEO}_{i t}+\beta_{4} \mathrm{BOC}_{\mathrm{it}}+\beta_{5} \mathrm{Size}_{\mathrm{it}}+\beta_{6} \mathrm{Age}_{\mathrm{it}}+$ $\beta_{7}$ Leverage $_{i t}+\varepsilon$

\section{Data dan Metode Pengumpulan Data}

Sampel penelitian adalah semua perusahaan manufaktur yang terdaftar di Bursa Efek Indonesia pada tahun 2009 sampai 2013. 
Tabel 1

Definisi Operasionalisasi Variabel

\begin{tabular}{|c|c|}
\hline Kualitas Audit & $\begin{array}{l}\text { Dalam penelitian ini kualitas audit diukur dengan dua cara. } \\
\text { Pertama, ukuran KAP yang diklasifikasi menjadi Big } 4 \text { atau non- } \\
\text { Big 4. Kedua, ukuran KAP yang diklasifikasi menjadi Big 4, } \\
\text { second tier dan lainnya. Mengacu pada penelitian Soedibyo } \\
\text { (2010), kategori second tier adalah KAP dengan jumlah staff } \\
\text { profesional antara } 100-400 \text { orang. Sedangkan kategori "lainnya" } \\
\text { adalah KAP third tier dengan jumlah staff profesional <100 } \\
\text { orang. }\end{array}$ \\
\hline \multicolumn{2}{|c|}{ Variabel Independen } \\
\hline D-Own & $\begin{array}{l}\text { Kendali melalui Kepemilikan langsung pihak keluarga } \\
\text { Merupakan total kendali pihak keluarga yang diperoleh melalui } \\
\text { kepemilikan langsung (Chung dan Chan, 2012). }\end{array}$ \\
\hline P-Own & $\begin{array}{l}\text { Total kendali yang diperoleh melalui mekanisme kepemilikan } \\
\text { piramida. Pada penelitian ini, kepemilikan yang membentuk } \\
\text { struktur piramida, langkah yang harus dilakukan terlebih } \\
\text { dahulu adalah menelusuri ultimate owner atau pemilik akhir dari } \\
\text { perusahaan publik yang menjadi sampel penelitian. } \\
\text { Setelah menemukan pemilik akhir dari sebuah perusahaan, } \\
\text { kemudian diidentifikasi hubungan kekerabatan antara pemilik } \\
\text { akhir dengan pemegang saham lainnya untuk menentukan } \\
\text { seberapa besar pengendalian pemilik akhir tersebut melalui } \\
\text { kepemilikan yang membentuk struktur piramida. Hal ini } \\
\text { dilakukan karena pada umumnya, setiap pihak yang memiliki } \\
\text { hubungan kekerabatan mengambil keputusan secara kolektif } \\
\text { demi menselaraskan tujuannya masing-masing (La Porta et al., } \\
\text { 1999). Pihak keluarga dikategorikan memiliki pengendalian } \\
\text { melalui mekanisme kepemilikan piramida apabila rangkaian } \\
\text { kepemilikan keluarga melalui perusahaan lain mendominasi } \\
\text { kepemilikan langsungnya. }\end{array}$ \\
\hline Family-CEO & $\begin{array}{l}\text { Pendiri perusahaan yang menduduki posisi pemimpin } \\
\text { perusahaan diduga dapat memberikan dampak positif terhadap } \\
\text { kinerja perusahaan karena mampu memitigasi konflik keagenan } \\
\text { antara pemegang saham dengan manajemen perusahaan karena } \\
\text { adanya suatu socioemotional wealth dengan menyelaraskan } \\
\text { tujuan manajemen dengan tujuan keluarga (Anderson dan Reeb, } \\
\text { 2003; Liu et al., 2010). Dalam mengukur kepemimpinan } \\
\text { keluarga, Pendiri perusahaan yang menduduki posisi pemimpin } \\
\text { perusahaan seperti direktur utama atau CEO dijadikan sebagai } \\
\text { proksi (Anderson dan Reeb, 2003). Variabel ini merupakan } \\
\text { variabel dummy yang bernilai } 1 \text { (satu) apabila pendiri } \\
\text { perusahaan menduduki posisi pimpinan perusahaan, dan } 0 \\
\text { (nol) jika lainnya. }\end{array}$ \\
\hline BOC & $\begin{array}{l}\text { Untuk mengukur efektifitas dewan komisaris, peneliti merujuk } \\
\text { pada pertanyaan-pertanyaan yang terdapat dalam ASEAN }\end{array}$ \\
\hline
\end{tabular}




\begin{tabular}{ll}
\hline \hline & Corporate Governance Scorecard yang dikeluarkan oleh ASEAN \\
& Capital Market Forum (ACMF). Pada bagian responsibility of board \\
& terdapat 74 pertanyaan dengan lima aspek utama, yaitu board \\
& duties and responsibility, board structure, board processes, people of \\
& the board dan board performance. Pertanyaan yang tertera dalam \\
& scorecard menghasilkan jawaban berupa yes or no. Namun \\
& demikian, scorecard yang dibuat oleh ACMF menilai kinerja \\
& Dewan Komisaris dan Dewan Direksi. Mengingat bahwa \\
& penelitian ini hanya ingin melihat efektivitas Dewan Komisaris, \\
& pertanyaan-pertanyaan yang tidak berkaitan dengan Dewan \\
& Komisaris dihilangkan. Pertanyaan tersebut mencakup peran \\
& Sekretaris Perusahaan, perencanaan rapat Dewan Direksi, peran \\
& audit internal, dan pengawasan atas risiko perusahaan yang \\
& dilakukan oleh mekanisme kontrol internal perusahaan. Jika \\
& jawaban pertanyaan adalah yes maka akan memberikan nilai 1 \\
& dan sebaliknya jika jawabannya adalah no akan memberikan \\
& nilai 0. Nilai maksimum dari scoring efektifitas Dewan \\
& Komisaris adalah 63 dan minimumnya adalah 0. Semakin tinggi \\
& nilai scoring yang dihasilkan maka semakin efektif fungsi \\
& pengawasan yang dijalankan oleh Dewan Komisaris. \\
\hline Variabel Kontrol & \\
\hline Perubahan & Dihitung sebagai selisih laba bersih perusahaan tahun t dengan \\
Profitabilitas & tahun t-1 dibagi dengan total aset awal tahun. \\
\hline Grow & Merupakan pertumbuhan perusahaan yang diukur dengan \\
perbandingan nilai pasar ekuitas dengan nilai buku ekuitas \\
pada akhir tahun \\
\hline Pengukuran variabel ini menggunakan pengukuran total utang \\
dibagi dengan total aset (Sweeney, 1994; Scott, 2010; Klein, 2002; \\
Lobo dan Zhou, 2006, Jenkins et al., 2006) \\
Ukuran perusahaan yang diproksikan dengan logaritma \\
normal nilai pasar ekuitas perusahaan pada akhir tahun seperti \\
yang digunakan oleh Siregar dan Utama (2008), Hermawan \\
(2009), Petra (2007), Farahmita (2009), dan Ghosh dan Moon \\
(2005)
\end{tabular}

Data sekunder yang digunakan adalah data kepemilikan pengendali akhir melalui penelusuran kepemilikan akhir perusahaan baik kepemilikan keluarga maupun kepemilikan asing (ASTINDO), yang terdapat pada Tambahan Berita Negara yang tersimpan di Perpustakaan Fakultas Hukum UI, Perpustakaan Percetakan Negara RI, dan Departemen Hukum dan Kehakiman serta dari PDBI (Pusat Data Bisnis Indonesia). Data harga saham dan laporan keuangan berasal dari basis data data stream,
IDX, dan ICMD serta data lainnya. Untuk data kualitas audit diperoleh dari Pusat Pembinaan Profesi Keuangan-Kementrian Keuangan dan Direktorat Jendral Pajak. Indeks penilaian efektifitas Dewan Komisaris diperoleh dengan menghitung skor Asean CG Scorecard berdasarkan informasi yang tertera dalam laporan tahunan perusahaan. Berikut akan disajikan contoh penelusuran hak kendali melalui kepemilikan piramida PT Tiga Pilar Sejahtera Food, Tbk (Diyanty, 2012). 


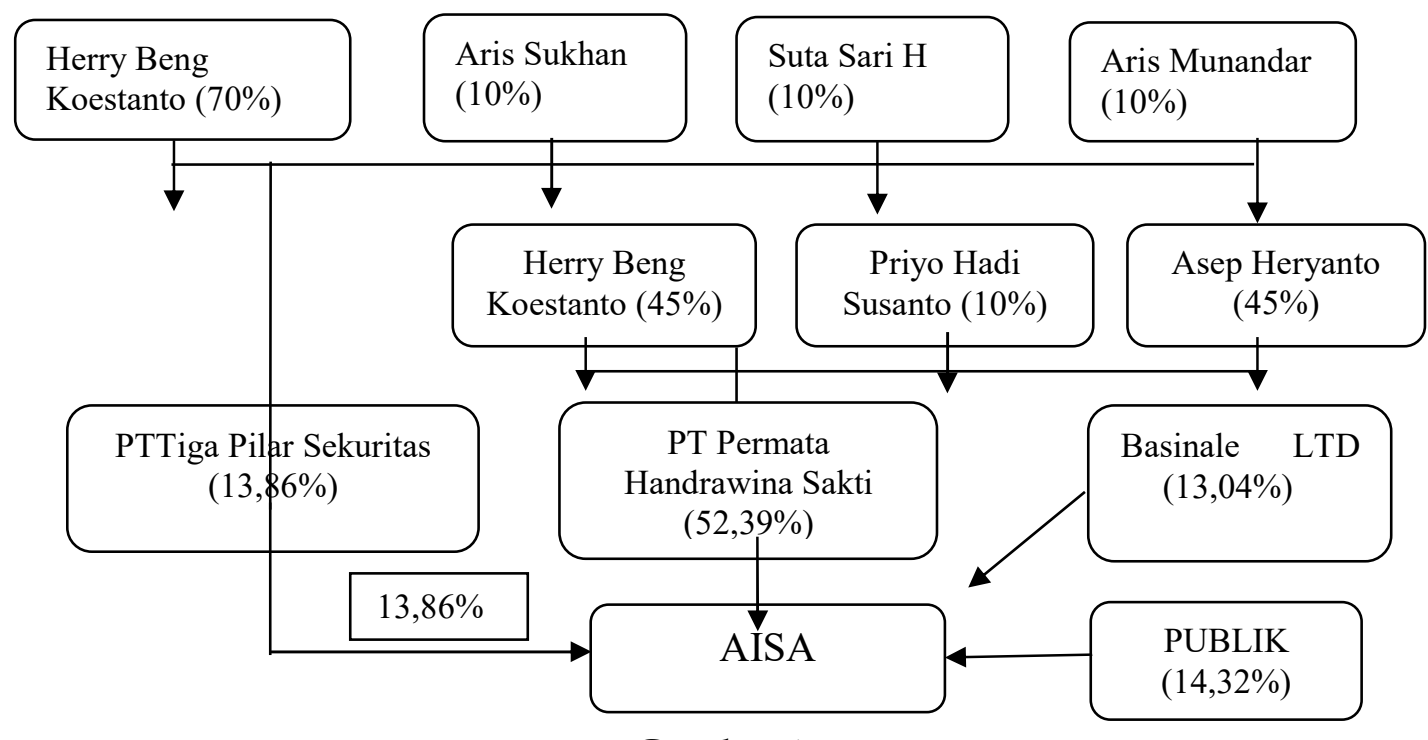

Gambar 1

Kepemilikan Ultimat PT Tiga Pilar Sejahtera Food, Tbk.

\section{Teknik Analisis Data}

Prosedur yang digunakan dalam menganalisis data adalah menggunakan model regresi berganda dengan OLS dan Regresi Tobit. Karena data untuk model 1, 2 dan 3 adalah kombinasi dari data time series dan data cross section maka akan dilakukan pengujian dengan data panel. Program yang digunakan adalah Stata. Pengujian hipotesis dilakukan dengan melakukan uji-t terhadap koefisien regresi. Uji F juga dilakukan untuk melakukan uji signifikansi koefisiensi regresi secara bersama-sama.

\section{ANALISIS DAN PEMBAHASAN \\ Hasil Seleksi Sampel}

Hasil regresi untuk model ini diregresikan selama 5 tahun dengan tahun observasi 2009-2013. Dengan kriteria yang telah ditentukan pada bagian metodologi penelitian, ditemukan sampel sebanyak 195 perusahaan keluarga sehingga total observasi dari tahun 2009 s/d 2013 sebesar 985 observasi. Ringkasan hasil seleksi sampel dapat dilihat pada tabel 2 .

Tabel 2

Ringkasan Pemilihan Sampel

\begin{tabular}{clr}
\hline \hline No & Kriteria Sampel & 453 \\
\hline 1 & Perusahaan yang telah terdaftar di BEI tahun 2013 & 79 \\
2 & Perusahaan yang tergolong dalam industri keuangan & 7 \\
3 & Perusahaan yang memiliki ekuitas negatif & 59 \\
4 & Perusahaan Non-BUMN yang melakukan pencatatan dalam mata uang asing* & \\
& Tidak dapat ditelusuri kepemilikannya dan tidak terdaftar di bursa efek & 24 \\
5 & secara berturut turut dari tahun 2009 sampai dengan 2013 & 89 \\
6 & Perusahaan yang dikendalikan oleh pemerintah & 195 \\
\hline & Perusahaan yang dikendalikan oleh pihak asing** & Jumlah sampel perusahaan keluarga
\end{tabular}

Sumber: hasil olah peneliti

Total observasi sebanyak 985 observasi 


\section{Analisis Statistik Deskriptif}

Tabel 3 menunjukkan bahwa pengendalian keluarga melalui kepemilikan langsung secara rata memiliki nilai sebesar $16 \%$ dengan nilai maksimum sebesar 93\%. Pengendalian melalui kepemilikan yang membentuk struktur piramida memiliki nilai rata-rata sebesar $31 \%$ dengan maksimum pengendalian sebesar $98 \%$. Dengan demikian dapat disimpulkan sebagian besar pengendalian terbesar keluarga diperoleh melalui kepemilikan piramida cukup besar. Hal ini konsisten dengan hasil sebelumnya.

Tabel 3

Statistik Deskriptif Pengaruh Kendali Keluarga Kualitas Auditor

\begin{tabular}{lccccc}
\hline \hline \multicolumn{1}{c}{ Variabel } & $\mathbf{N}$ & Mean & Std. Dev & Min & Max \\
\hline D-Own & 985 & 0.16 & 0.26 & 0 & 0.93 \\
P-Own & 985 & 0.31 & 0.28 & 0 & 0.98 \\
Size & 985 & 27.48 & 2.03 & 22.97 & 33.36 \\
Leverage & 985 & 0.22 & 0.19 & 0 & 0.86
\end{tabular}

$\begin{array}{lcc}\quad \text { Variabel } & \text { Frequency Nilai 0 } & \text { Frekuensi Nilai } 1 \\ 2 \text { kategori KAP } & 66.99 \% & 33.01 \% \\ \text { Fam-CEO } & 58.37 \% & 41.63 \%\end{array}$

\begin{tabular}{cccc} 
Variabel & Frequency Nilai 1 & Frekuensi Nilai 2 & Frekuensi Nilai 3 \\
3 kategori KAP & $32.77 \%$ & $44.78 \%$ & $22.45 \%$ \\
\hline
\end{tabular}
Sumber: hasil olah peneliti

Data penelitian menunjukkan bahwa hanya sekitar 33.01 dari total observasi, perusahaan memilih auditor Big4 untuk mengaudit perusahaan sisanya adalah auditor non Big 4. Hasil ini menunjukkan bahwa kecenderungan perusahaan lebih banyak memilih auditor non Big4 untuk mengaudit perusahaannya. Analisis tambahan atas auditor berdasarkan tiga kategori yaitu Big4, second tier dan lainnya, menunjukkan bahwa proporsi terbesar perusahaan sampel memilih auditor second tier yaitu $44.78 \%$. Setengah dari sampel lainnya sebesar $32.77 \%$ memilih auditor Big4 dan sisanya $22.45 \%$ memilih auditor lainnya. Hasil ini menunjukkan peran auditor second tier yang makin besar pada perusahaan perusahaan publik di Indonesia, karena auditor second tier dipersepsikan memiliki kualitas yang tidak jauh berbeda dengan auditor Big4 namun menawarkan biaya audit yang lebih rendah dibandingkan auditor Big4. Dari jumlah sample perusahaan keluarga yang menjadi sampel penelitian, perusahaan yang dipimpin oleh pendiri perusahaan sebesar $58.37 \%$ sebegai CEO perusahaan. Rasio utang jangka panjang terhadap total aset (leverage) perusahaan memiliki nilai rata-rata 0.22 dengan standar deviasi sebesar 0.19. Dari data ini dapat disimpulkan bahwa lebih dari setengah perusahaan keluarga tidak bergantung pada pembiayaan yang berasal dari utang.

\section{Hasil Regresi}

Tabel 4 menunjukkan analisis atas pengaruh kepemilikan keluarga baik secara langsung ataupun piramidal terhadap pemilihan auditor. Tabel 3 menunjukkan bahwa model 1 terbukti signifikan pada tingkat keyakinan 99\% sehingga dapat disimpulkan bahwa secara keseluruhan model secara bersama-sama memiliki pengaruh yang signifikan terhadap variabel terikat yaitu probabilitas pemilihan auditor Big 4 dibandingkan auditor second tier atau auditor lainnya. 
Tabel 4

Hasil Regresi

$\mathrm{AQ}=\mathrm{\alpha}+\beta_{1} \mathrm{D}-\mathrm{Own} \mathrm{it}_{\mathrm{it}}+\beta_{2} \mathrm{P}-\mathrm{Own}_{\mathrm{it}}+\beta_{3} \mathrm{Fam}_{-\mathrm{CEO}}+\beta_{4} \mathrm{BOC}_{\mathrm{it}}+\beta_{5} \mathrm{Size}_{\mathrm{it}}+\beta_{6} \mathrm{Age}_{\mathrm{it}}+\beta_{7}$ Leverage $_{\mathrm{it}}$

$+\varepsilon$

\begin{tabular}{|c|c|c|c|}
\hline Dependen: AQ & Hipotesis & Coefficient & P-value \\
\hline \multicolumn{4}{|c|}{ Kategori 2} \\
\hline D-Own & - & -1.085 & 0.011 \\
\hline P-Own & + & -0.632 & 0.083 \\
\hline Fam-CEO & - & -0.303 & 0.071 \\
\hline BOC & - & -0.762 & 0.274 \\
\hline Size & & -0.145 & 0.390 \\
\hline Leverage & & -0.595 & 0.000 \\
\hline Age & & -0.032 & 0.000 \\
\hline \multicolumn{4}{|c|}{ Kategori 3} \\
\hline D-Own & + & -1.307 & 0.011 \\
\hline P-Own & - & 0.899 & 0.054 \\
\hline Fam-CEO & + & 0.365 & 0.076 \\
\hline BOC & + & 4.029 & 0.005 \\
\hline Size & & -0.536 & 0.196 \\
\hline Leverage & & -0.784 & 0.000 \\
\hline Age & & -0.071 & 0.000 \\
\hline \multicolumn{4}{|c|}{$\mathrm{N}=824$} \\
\hline & & \multicolumn{2}{|c|}{ LR chi2 $=297,29$} \\
\hline & & \multicolumn{2}{|c|}{ Prob $>$ chi $2=0,0000$} \\
\hline & & \multicolumn{2}{|c|}{$\mathrm{R} 2=0,17$} \\
\hline
\end{tabular}

\section{Keterangan Tabel:}

AQ = Audit Quality; KAP Big4=1, Secondtier =2, others =3, D-Own = Kepemilikan langsung pihak keluarga. $\mathbf{P}$-Own = Kepemilikan pihak keluarga yang membentuk struktur piramida. Family-CEO = Kepemimpinan keluarga; bernilai 1 jika CEO perusahaan merupakan anggota keluarga dan 0 jika tidak berasal dari keluarga. $\mathbf{B O C}=$ Efektivitas dewan komisaris, bernilai 1 jika jawaban ya dan 0 sebaliknya. Age $=$ Umur perusahaan. Size = Ukuran perusahaan; logaritma natural dari total sset perusahaan. Leverage = leverage perusahaan; utang jangka panjang dibagi total sset perusahaan.

Sumber : Hasil output STATA

Hasil regresi menunjukkan bahwa kendali keluarga baik melalui mekanisme kepemilikan langsung maupun kepemilikan tidak langsung terbukti menunjukkan bahwa perusahaan keluarga lebih cenderung memilih auditor Big 4 untuk mengaudit perusahaan yang dikendalikannya dibandingkan auditor second tier ataupun auditor lainnya. Dengan demikian hasil penelitian menunjukkan bahwa perusahaan yang dikendalikan keluarga berkecenderungan untuk memilih auditor Big 4 di- 
bandingkan second tier ataupun auditor lainnya. Hasil ini konsisten dengan penelitian Kang (2014) yang menunjukkan bahwa perusahaan keluarga memiliki insentif yang besar untuk memberikan sinyal kepada public bahwa laporan keuangan mereka berkualitas tinggi. Pemegang saham pengendali keluarga baik secara langsung ataupun piramidal cenderung melepaskan manfaat jangka pendek untuk menjaga reputasi keluarga dan untuk mewariskan bisnis yang berkelanjutan kepada pewarisnya (alignment effect). Tabel 4 juga menunjukkan bahwa manajemen puncak yang berasal dari keluarga pendiri juga berkomitmen untuk memilih auditor berkualitas tinggi yaitu auditor Big4 untuk menjaga reputasi keluarga. Hal ini sejalan dengan hasil sebelumnya bahwa perusahaan keluarga ingin menjaga reputasi perusahaannya.

Penempatan pendiri perusahaan pada posisi top management, akan makin menyelaraskan kepentingan manajmen dengan kepentingan pemegang saham pengendali dalam mempertahankan socioemotional wealth agar terjaga kesinambungan perusahaan (alignment effect). Tata kelola perusahaan yang diproksi dengan efektivitas dewan komisaris terbukti tidak berpengaruh terhadap pilihan KAP antara Big 4 ataupun second tier. Namun jika dibandingkan dengan KAP "lainnya", efektivitas dewan komisaris terbukti berdampak pada preferensi KAP Big 4 dibandingkan dengan KAP "lainnya". Dengan demikian dapat disimpulkan bahwa dewan komisaris yang efektif akan mendukung kualitas audit yang lebih baik untuk menjaga reputasi perusahaan serta kesinambungan perusahaan.

\section{SIMPULAN}

Penelitian ini dilakukan untuk melihat pengaruh dari pemegang saham pengendali pengendalian keluarga baik yang diperoleh melalui mekanisme kepemilikan langsung dan piramida terhadap kualitas auditerta bagaimana kepemimpinan keluarga dari keluarga pengendali melalui mekanisme langsung dan mekanisme piramidal dan efektivitas dewan komisaris mempengaruhi hubungan tersebut.

Untuk menelusuri kepemilikan keluarga di suatu perusahaan, peneliti mengguna kan laporan tahunan perusahaan yang didapat dari Thomson Reuters Eikon sebagai sumber utama, dan dilanjutkan dengan menelurusi website Bursa Efek Indonesia dan website perusahaan untuk mencari laporan tahunan perusahaan. Terdapat beberapa laporan tahunan perusahaan yang mengungkapkan pengendali utamanya (ultimate owner), dan untuk laporan tahunan yang tidak mengungkapkan pemilik utamanya peneliti menggunakan data yang diambil dari Departemen Administrasi Hukum Umum, Kementerian Hukum dan HAM Republik Indonesia untuk menelusuri pemilik utama dari perusahaan tersebut. Selain itu dari laporan tahunan perusahaan didapatkan juga data pemimpin perusahaan, efektivitas dewan komisaris, dan juga umur perusahaan. Untuk menentukan apakah pimpinan utama perusahaan tersebut merupakan pendiri perusahaan, digunakan data hubungan keluarga yang ada pada penelitian Diyanty (2012). Untuk data auditor diperoleh data P2PK (Pusat Pembinaan Profesi Keuangan). Kemudian peneliti menggunakan Data Stream Profesional dari Thomson Reuters untuk mendapatkan data kinerja perusahaan dan data variabel kontrol lainnya.

Hasil penelitian terkait dengan pengaruh kepemilikan keluarga dan peran pendiri perusahaan sebagai pimpinan utama perusahaan terhadap kualitas audit menunjukkan bahwa (1) Hasil regresi menunjukkan bahwa kendali keluarga baik melalui mekanisme kepemilikan langsung maupun kepemilikan tidak langsung terbukti menunjukkan bahwa perusahaan keluarga lebih cenderung memilih auditor Big 4 untuk mengaudit perusahaan yang dikendalikannya dibandingkan auditor second tier ataupun auditor lainnya. (2) 
Pimpinan utama perusahaan yang berasal dari keluarga pendiri terbukti positif terhadap kualitas audit. (3) Tata kelola perusahaan yang diproksi dengan efektivitas dewan komisaris terbukti tidak berpengaruh terhadap pilihan KAP antara Big 4 ataupun second tier. Namun jika dibandingkan dengan KAP "lainnya", efektivitas dewan komisaris terbukti berdampak pada preferensi KAP Big 4 dibandingkan dengan KAP "lainnya". Dengan demikian dapat disimpulkan bahwa dewan komisaris yang efektif akan mendukung kualitas audit yang lebih baik.

\section{DAFTAR PUSTAKA}

Almeida, H. V. dan D. Wolfenzon. 2006. A Theory of Pyramidal Ownership and Family Business Group. The Journal of finance 61(6): 2637-2680.

Anderson, R. C. dan D. M. Reeb. 2003. Founding-Family Ownership and Firm Performance: Evidence from the S\&P 500. The Journal of Finance 58(3): 13011328.

Balsam, S., J. Krishnan, dan J. S. Yang. 2003. Auditor Industry Specialization and Earnings Quality. Auditing: A Journal of Practice and Theory 22(2): 71-97.

Bamber, E. M. dan L. S. Bamber, 2009. Discussion of Mandatory Audit Partner Rotation, Audit Quality, and Market Perception: Evidence from Taiwan. Contemporary Accounting Research 26(2): 393-402.

Becker, C. L., M. L. Defond, J. Jiambalvo, dan K. R. Subramanyam. 1998. The Effect of Audit Quality on Earnings Management. Contemporary Accounting Research 15(1): 1-24.

Bloom, R. dan D. Schirm. 2008. An Analysis of the GAO Study on Audit Market Concentration. The CPA Journal 78(4): 6 .

Choi, J., S. Kwak, dan H. Yoo. 2008. The Effect of Divergence between Cash Flow Right and Voting Right on Audit
Hour and Audit Fee per Audit Hour. Seoul Journal of Business 14(1): 55-77.

Claessens, S., S. Djankov, dan L. H. P. Lang. 1999a. Who Control East Asia Corporations. Working Paper. World Bank. Washington DC.

Claessens, S., S. Djankov, J. R. H. Fan, dan L. H. P. Lang. 1999b. Expropriations of Minority Shareholders; Evidence from East Asia. Working Paper World Bank. Washington DC.

Claessens, S., S. Djankov, dan L. H. P. Lang. 2000. The Separation of Ownership and Control in East Asian Corporation. Journal of Financial Economics 58(1-2): 81112.

Chua, J. H., J. J. Chrisman, dan P. Sharma. 1999. Defining the Family Business by Behavior. Entrepreneurship: Theory and Practice 23: 19-40.

Chung, H. M. dan S. T. Chan. 2012. Ownership Structure, Family Leadership, and Performance of Affiliate Firms in Large Family Business Groups. Asia Pacific Journal of Management 29(2): 303-329.

Darmadi, S. 2016. Ownership Concentration, Family Control, and Auditor Choice: Evidence from an Emerging Market. Asian Review of Accounting 24(1): 19-42.

DeAngelo, L. E. 1981. Auditor Size and Audit Quality. Journal of Accounting and Economics 3(3): 183-199.

Diyanty, V. 2012. Pengaruh Kepemilikan Pengendali Akhir terhadap Traksaksi Pihak Berelasi dan Kualitas Laba. Disertasi. Program Pasca Sarjana Akuntansi Universitas Indonesia. Depok.

El Ghoul, S., O. Guedhami, C. Lennox, dan J. A. Pittman. 2007. Ownership Structure, Agency Problems, and Auditor Choice: Evidence from Western European Firms. Proceedings of the Annual Conference of the Administrative Science Association of Canada 28(26). 
Faccio, M. dan L. H. P. Lang. 2002. The Ultimate Ownership of Western European Corporations. Journal of Financial Economics 65(3): 365-395.

Fan, J. P. H. dan T. J. Wong. 2002. Corporate Ownership Structure and the Informativeness of Accounting Earning in East Asia. Journal of Accounting and Economics 33(3): 401-425.

Fan, J. P. H. dan T. J. Wong. 2005. Do External Auditors Perform a Corporate Governance Role in Emerging Markets? Evidence from East Asia. Journal of Accounting Research 43(1): 35-72.

Farahmita, A. 2009. Pengaruh Praktik Corporate Governance terhadap Hubungan antara Transaksi Pihak Berelasi (Related Party Transaction) dengan Manajemen Laba. Tesis. Program Ilmu Magister Sains Manajemen Keuangan Universitas Indonesia. Depok.

Francis, J. R. 2004. What Do We Know about Audit Quality?. The British Accounting Review 36(4): 345-368.

Francis, J. R. dan M. D. Yu. 2009. Big 4 Office Size and Audit Quality. The Accounting Review 84(5): 1521-1552.

Gómez-Mejía, L. R., K. T. Haynes, M. Núñez-Nickel, K. J. L. Jacobson, dan J. Moyano-Fuentes. 2007. Socioemotional Wealth and Business Risks in Family-controlled Firms: Evidence from Spanish Olive Oil Mills. Administrative Science Quarterly 52(1): 106-137.

Francis, J. R., E. L. Maydew, dan H. C. Sparks. 1999. The Role of Big 6 Auditors in the Credible Reporting of Accruals. Auditing: A Journal of Practice and Theory 18(2): 17-34.

Ghosh, A. dan D. Moon. 2005. Auditor Tenure and Perceptions of Audit Quality. The Accounting Review 80(2): 585-612.

Gomes, A. 2000. Going Public without Governance: Managerial Reputation Effects. The Journal of Finance 55(2): 615646.
Hay, D., W. R. Knechel, dan H. Ling. 2008. Evidence on the Impact of Internal Control and Corporate Governance on Audit Fees. International Journal of Auditing 12(1): 9-24.

Hermawan, A. 2009. Pengaruh Efektifitas Dewan Komisaris dan Komite Audit, Kepemilikan oleh Keluarga, dan Peran Monitoring Bank terhadap Kandungan Informasi Laba. Disertasi. Fakultas Ekonomi Universitas Indonesia.

James, H. S. 1999. Owner as Manager, Extended Horizons and the Family Firm. International Journal of the Economis of Business 6(1): 41-55.

Jensen, M. C. dan W. H. Meckling. 1976. Theory of the Firm: Managerial Behaviour, Agency Costs and Ownership Structure. Journal of Financial Economics 3(4): 305-360.

Jenkins, D. S., G. D. Kane, dan U. Velury. 2006. Earning Quality Decline and the Effect of Industry Specialist Auditors: an Analysis of the Late 1990s. Journal of Accounting and Public Policy 25(1): 71-90.

Kang, F. 2014. Founding Family Ownership and the Selection of Industry Specialist Auditors. Accounting Horizons 28(2): 261-276.

Khan, A. R., D. M. Hossain, dan J. Siddiqui. 2011. Corporate Ownership Concentration and Audit Fees: the Case of an Emerging Economy. Advances in Accounting 27(1): 125-131.

Suk, K. S. 2006. Hubungan Simultan antara Struktur Kepemilikan, Corporate Governance, dan Nilai Perusahaan dari Perusahaan di Bursa Efek Jakarta. Disertasi. Fakultas Ekonomi Universitas Indonesia.

Klein, A. 2002. Audit Committee, Board of Director Characteristics, and Earning Managements. Journal of Accounting and Economics 33(3): 375-400.

La Porta, R., F. Lopez-De-Silanes, dan A. Shleifer. 1999. Corporate Ownership around the World. The Journal of Finance 54(2): 471-517. 
Lin, Z. J. dan M. Liu. 2009. The Impact of Corporate Governance on Auditor Choice: Evidence from China. Journal of International Accounting, Auditing, and Taxation 18(1): 44-59.

Liu, W., H. Yang, dan G. Zhang. 2010. Does Family Business Excel in Firm Performance? An Institutionbased View. Asia Pacific Journal of Management 29(4): 965-987.

Lobo, G. J. dan J. Zhou. 2006. Did Conservatism in Financial Reporting Increase after Sarbanes-Oxley? Initial Evidence. Accounting Horizon 20(1): 57-73.

Lukviarman, N. 2004. Ownership Structure and Firm Performance: The Case of Indonesia. Disertasi. Graduate School of Business, Curtain University of Technology. Perth.

Maharani, D. 2011. Analisis Mekanisme Corporate Governance Perusahaan terhadap Pemilihan Auditor Eksternal. Publikasi Simposium Nasional Akuntansi.

Mayangsari, S. 2004. Bukti Empiris Pengaruh Spesialisasi Industri Auditor terhadap Earnings Response Coefficient. The Indonesian Journal of Accounting Research 7(2).

Peng, M. W. dan Y. Jiang. 2010. Institutions behind Family Ownership and Control in Large Firms. Journal of Management Studies 47(2): 253-273.

Petra, S. T. 2007. The Effects of Corporate Governance on the Informativeness of Earnings. Economics of Governance 8(2): 129-152.

Putra, D. 2015. Pengaruh Mekanisme Corporate Governance Terhadap Pemilihan Auditor Eksternal. Prosiding Sembistek 2014, 1(01): 148-159.

Reynolds, J. K. dan J. R. Francis. 2000. Does Size Matter? The Influence of Large Clients on Office-Level Auditor Reporting Decisions. Journal of Accounting and Economics 30(3): 375-400.
Scott, W. R. 2010. Financial Accounting Theory. $6^{\text {th }}$ Edition. Pearson PrenticeHall.

Shleifer, A. dan R. W. Vishny. 1986. Large Shareholders and Corporate Control. Journal of Political Economy 94(3): 461488.

Simunic, D. A. 1980. The Pricing of Audit Services: Theory and Evidence. Journal of Accounting Research 18(1): 161-190.

Siregar, S. V. dan S. Utama. 2008. Type of Earnings Managements and the Effect of Ownership Structure, Firm Size, and Corporate Governance Practices: Evidence from Indonesia. The International Journal of Accounting 43(1): 1-27.

Siregar, S. V. N. P. dan S. Utama. 2006. Pengaruh Struktur Kepemilikan, Ukuran Perusahaan, dan Praktek Corporate Governance terhadap Pengelolaan Laba (Earnings Management). Jurnal Riset Akuntansi Indonesia 9(3): 307-326.

Sweeney, A. P. 1994. Debt Covenant Violations and Manager's Accounting Responses. Journal of Accounting and Economics 17(3): 281-308.

Ulupui, I. G. K. 2009. Pengaruh Struktur Kepemilikan, Praktik Governance terhadap Kompensasi Direksi, Komisaris dan Dampak Ekses Kompensasi terhadap Kinerja Perusahaan. Disertasi. Program Pasca Sarjana Ilmu Manajemen, Universitas Indonesia. Depok.

Yeh, Y. H. 2005. Do Controlling Shareholders Enhance Corporate Value? Corporate Governance: an International Review 13(2): 313-325.

Watkins, A. L., W. Hillison, dan S. E. Morecroft. 2004. Audit Quality: A Synthesis of Theory and Empirical Evidence. Journal of Accounting Literature 23(2004): 153-193.

Watts, R. L. dan Zimmerman, J. L. 1986. The Positive Accounting Theory. Prentice Hall Inc. New Jersey. 